Original Research Article

\title{
Antibiotic susceptibility pattern of bacteria isolated from patients of respiratory tract infection in a tertiary care hospital of Eastern India
}

\author{
Ashok Prasad ${ }^{1}$, Shatavisa Mukherjee ${ }^{2}$, Nikhil Era ${ }^{3 *}$, Mala Mukherjee ${ }^{4}$
}

\begin{abstract}
${ }^{1}$ Department of Microbiology, ${ }^{3}$ Department of Pharmacology, ${ }^{4}$ Department of Pathology, MGM Medical College and LSK Hospital, Kishanganj, Bihar, India

${ }^{2}$ Department of Clinical and Experimental Pharmacology, School of Tropical Medicine, Kolkata, West Bengal, India
\end{abstract}

Received: 04 February 2019

Revised: 28 February 2019

Accepted: 14 March 2019

*Correspondence to:

Dr. Nikhil Era,

Email: nikhilera@yahoo.com

Copyright: (๑) the author(s), publisher and licensee Medip Academy. This is an openaccess article distributed under the terms of the Creative Commons Attribution NonCommercial License, which permits unrestricted noncommercial use, distribution, and reproduction in any medium, provided the original work is properly cited.

\begin{abstract}
Background: Respiratory tract infections have been one of the commonest types of infections affecting the Indian population. With antibiotic resistance being a global threat and challenge to healthcare, concerns over skilful and judicious use of existing antibiotics have been on rise. Update on region specific bacterial susceptibility pattern is thus a need. The present study was planned to identify the common pathogens responsible for the respiratory tract infection and their antibiotic susceptibility patterns.

Methods: A prospective study was carried out, where subjects with lower respiratory tract (LRT) infection admitted in the Intensive Care Unit in the tertiary care centre in Eastern India during the one-year period were enrolled in the study. Samples such as sputum, suction tip, endotracheal aspirate, bronchial aspirate and pleural fluid were obtained under aseptic precautions and were processed. The bacterial isolates were subjected to susceptibility testing by standard Kirby Bauer disc diffusion methods. The susceptibility patterns of the bacterial pathogens were determined.

Results: Out of 234 processed samples, klebsiella (33.44\%) was found to be commonest pathogen isolated from all the sites followed by Pseudomonas, staphylococcus and others. Amongst the penicillin group of antibiotics, ampicillin showed highest activity against pseudomonas and E. coli respectively. Antibiotics like penicillin G, ampicillin/sulbactam and amoxicillin/clavulanic acid combination showed lower susceptibility towards most pathogens. Amongst broad spectrum antibiotics, amikacin showed high susceptibility towards pseudomonas species followed by chloramphenicol and tetracycline.

Conclusions: With changing trends in microbiological patterns of responsible organisms, knowledge regarding antibiotic susceptibility pattern needs to be regularly revised, thus ensuring prompt initiation of adequate and appropriate antibiotic treatment with better patient outcomes.
\end{abstract}

Keywords: Antibiotic susceptibility, Antibiogram, Antibiotic policy, Respiratory tract infections

\section{INTRODUCTION}

Respiratory tract infections (RTIs) have been a significant contributor of morbidity and mortality. Evidences from numerous researches prove that multidrug resistance pathogens are rapidly emerging across the world posing a challenge to the health care. The antibiotic resistance crises are attributed to the over use and misuse of broad-spectrum antibiotics in hospitalized patients. ${ }^{1}$ Although the antimicrobial resistance has increased over a period of time, the development of novel antimicrobial agents has dramatically declined over the past decades. ${ }^{2}$ Hence, to combat the situation, judicious use of antibiotics is warranted. Robust community or hospital-based resistance data to determine appropriate empiric treatment for these infections is necessary which should be regularly updated, as bacterial susceptibility varies across time and space. ${ }^{3}$ With RTIs being one of the commonest infections 
affecting Indian population, region-specific antibiotic susceptibility pattern of respiratory pathogens is essential. Hence, the study was planned to identify the common respiratory pathogens responsible for the infection and explore their antibiotic susceptibility patterns.

\section{METHODS}

A prospective study was carried out in the tertiary care centre in Eastern India. Subjects with lower respiratory tract infection admitted in its critical care setting during the one-year period were enrolled in the study. After obtainment of written informed consent from the participants or their representatives, the samples such as sputum, suction tip, endotracheal aspirate, bronchial aspirate and pleural fluid were obtained under aseptic precautions and were processed immediately. Macroscopic appearance of the sample was noted for colour, consistency, quantity, and for presence of any pus or blood. Smears were prepared from the specimens and gram stains of all clinical samples were examined under compound microscope using oil immersion objective lens. Smears were examined for presence of pus cells, lymphocytes and epithelial cells. Gram reaction and arrangement of bacteria was seen.

Each sample was inoculated on blood agar and MacConkey's agar and incubated at $37^{\circ} \mathrm{C}$ for 24 hours and further for 48 hours if necessary, the organisms grown were identified on basis of their morphology, cultural characters and biochemical reactions according to standard procedures. Isolates from repeat culture of previously recruited patients and isolates identified as commensals or contaminants were excluded. The bacterial isolates were subjected to susceptibility testing by standard Kirby Bauer disc diffusion methods. The susceptibility patterns of the bacterial pathogens were determined following the panel of antimicrobial agents as recommended by Clinical Laboratory Standard Institute (CLSI) $-2010 .{ }^{4}$

\section{Preparation of plates}

Muller Hilton agar (Hi-Media) which was prepared from a commercially available dehydrated base according to manufacturer's instructions and was used for antimicrobial susceptibility testing. Representative sample of each batch of plates was examined for sterility by incubating at 35$37^{\circ} \mathrm{C}$ for $16-18$ hours or longer. Plates were completely dried with lids ajar to avoid moisture droplets presence on agar surface, prior inoculation.

\section{Preparation of inoculums}

At least 3-5 well-isolated, morphologically similar colonies from an agar medium were touched with a straight wire loop and growth was transferred to a test tube containing 4-5 $\mathrm{ml}$ of sterile peptone water. The tubes were incubated for 2 to $6 \mathrm{hrs}$ at $37^{\circ} \mathrm{C}$ to produce a bacterial suspension of moderate cloudiness.

\section{Inoculation}

Plates were inoculated within 15 minutes of preparation of suspension so that the density does not change. A sterile cotton swab was dipped into the suspension and surplus removed by rotation of the swab against the side of the tube above the fluid level. The medium was inoculated by even streaking of the swab over the entire surface of the plates in three directions.

\section{Applications of antibiotic discs}

Antibiotic discs were stored at $4^{\circ} \mathrm{C}$ in refrigerator. Discs were allowed to come to room temperature before further application. After the inoculated plates were dried antibiotic discs were applied to the agar surface with sterile forceps and gently pressed down to ensure contacts. They were distributed evenly so that they were not closer than $24 \mathrm{~mm}$ from centre to centre and not more than 8 discs were applied on $90 \mathrm{~mm}$ plate. Concentration of antibiotics used for testing susceptibility was according to CLSI guidelines. Zone diameter was measured in millimetres. The entire testing was done under strict quality control and American Type Culture Collection (ATCC) strains were used as control strains.

\section{RESULTS}

A total of 227 patients were enrolled for the present study and 265 samples were received in the microbiology department. 31 samples were excluded due to reasons such as contamination, inadequate quantity and poor labelling and the rest 234 samples were further processed. The samples obtained were from tracheal swab, endotracheal tube, pleural fluid, throat swab and sputum (Table 1).

Table 1: Distribution of obtained samples.

\begin{tabular}{|ll|}
\hline Samples obtained & N $(\%)$ \\
\hline Sputum & $91(38.89)$ \\
\hline Tracheal & $70(29.91)$ \\
\hline Endotracheal & $61(26.07)$ \\
\hline Pleural fluid & $6(2.56)$ \\
\hline Throat swab & $6(2.56)$ \\
\hline Total samples & 234 \\
\hline
\end{tabular}

The discriminative prevalence of various organisms across the sample site was assessed and Klebsiella (33.44\%) was found to be commonest pathogen isolated from all the sites followed by Pseudomonas (28.29\%), Staphylococcus $(14.79 \%)$ and others.

Klebsiella was the most prevalent organism isolated from trachea $(n=37)$, followed by sputum $(n=35)$ and endotracheal specimen $(\mathrm{n}=28)$. Pseudomonas was the most prevalent in sputum and in tracheal swab (Table 2).

Amongst the penicillin group of antibiotics, ampicillin showed highest activity against pseudomonas (79.54\%) 
and E. coli $(60.6 \%)$ respectively. This was followed by piperacillin/tazobactam combination $\quad(59.09 \%$ for pseudomonas and $54.54 \%$ for $E$. coli specimens).
Antibiotics like penicillin G, ampicillin/sulbactam and amoxicillin/clavulanic acid combination showed lower susceptibility towards most pathogens (Table 3).

Table 2: Prevalence of various organisms across difference sample sites.

\begin{tabular}{|lllllll|}
\hline Organism & No. of Samples $(\mathbf{n})$ & & & & Total (N(\%)) \\
\hline Acinetobacter & Sputum & Tracheal & Endotracheal & Pleural fluid & Throat swab & ( \\
\hline Enterobacter & 2 & 8 & 13 & 1 & Nil & $24(7.71)$ \\
\hline Enterobacteriaceae & 3 & Nil & 1 & Nil & Nil & $3(0.96)$ \\
\hline E. coli & 13 & 13 & 4 & Nil & 1 & $6(1.92)$ \\
\hline Klebsiella & 35 & 37 & 28 & 1 & 1 & $33(10.61)$ \\
\hline Pseudomonas & 31 & 29 & 23 & 3 & 3 & $104(33.44)$ \\
\hline Staphylococcus & 13 & 16 & 12 & 1 & 4 & $88(28.29)$ \\
\hline Streptococcus & 6 & 01 & Nil & Nil & Nil & $76(14.79)$ \\
\hline Total & & & & & & 311 \\
\hline
\end{tabular}

Table 3: Antibiotic susceptibility pattern.

\begin{tabular}{|c|c|c|c|c|c|c|c|c|c|}
\hline \multicolumn{2}{|l|}{ Antibiotic Class } & $\begin{array}{l}\text { Staphylo- } \\
\text { coccus }\end{array}$ & $\begin{array}{l}\text { Strepto- } \\
\text { coccus }\end{array}$ & $\begin{array}{l}\text { Pseudo- } \\
\text { monas }\end{array}$ & Klebsiella & $\begin{array}{l}\text { Acineto- } \\
\text { bacter }\end{array}$ & E. coli & $\begin{array}{l}\text { Entero- } \\
\text { bacter }\end{array}$ & $\begin{array}{l}\text { Entero- } \\
\text { bacteriaceae }\end{array}$ \\
\hline & & $\mathrm{N}=46$ & $\mathrm{~N}=7$ & $\mathrm{~N}=88$ & $\mathrm{~N}=104$ & $\mathrm{~N}=\mathbf{2 4}$ & $\mathbf{N}=33$ & $\mathbf{N}=\mathbf{3}$ & $\mathrm{N}=6$ \\
\hline \multirow{8}{*}{ Penicillin group } & Penicillin G & $3(6.5)$ & $1(14.3)$ & $11(12.5)$ & - & - & - & - & - \\
\hline & Ampicillin & - & $1(14.3)$ & $\begin{array}{l}70 \\
(79.54) \\
\end{array}$ & $46(44.23)$ & $5(20.8)$ & $20(60.6)$ & $1(33.3)$ & $2(33.33$ \\
\hline & Piperacillin & - & - & $\begin{array}{l}37 \\
(42.04)\end{array}$ & $9(8.65)$ & $2(8.3)$ & $2(6.06)$ & $1(33.3)$ & $1(16.66)$ \\
\hline & Ticarcillin & - & - & $14(15.9)$ & $5(4.81)$ & $1(4.16)$ & $1(3.03)$ & - & $1(16.66)$ \\
\hline & Oxacillin & $7(15.2)$ & - & $2(2.27)$ & $1(0.96)$ & $1(4.16)$ & - & - & - \\
\hline & Ampicillin/Sulbactum & - & - & - & $1(0.96)$ & $1(4.16)$ & $1(3.03)$ & - & $1(16.66)$ \\
\hline & $\begin{array}{l}\text { Amoxicillin/Clavulanic } \\
\text { acid }\end{array}$ & $20(43.5)$ & - & - & - & - & $7(21.21)$ & - & - \\
\hline & Piperacillin/Tazobactum & $3(6.52)$ & - & $\begin{array}{l}52 \\
(59.09)\end{array}$ & $30(28.85)$ & $4(16.67)$ & $18(54.54)$ & $1(33.3)$ & $2(33.33)$ \\
\hline \multirow{7}{*}{$\begin{array}{l}\text { Cephalosporin } \\
\text { group }\end{array}$} & Cefazoline & - & - & $1(1.13)$ & $9(8.65)$ & - & $3(9.09)$ & - & - \\
\hline & Cephalothin & $3(6.5)$ & - & $1(1.13)$ & $1(0.96)$ & - & - & - & - \\
\hline & Cefoxtin & $8(17.4)$ & - & $2(2.27)$ & $20(19.23)$ & $2(8.3)$ & $8(24.24)$ & - & $2(33.33)$ \\
\hline & Cephotaxime & - & - & $\begin{array}{l}17 \\
(19.32)\end{array}$ & $4(3.85)$ & $1(4.16)$ & $5(15.15)$ & $1(33.3)$ & $1(16.66)$ \\
\hline & Ceftazidime & - & - & $22(25)$ & $4(3.85)$ & $1(4.16)$ & $5(15.15)$ & - & $1(16.66)$ \\
\hline & Ceftriaxone & - & - & - & $1(0.96)$ & - & - & - & - \\
\hline & Cefepime & - & - & $22(25)$ & $4(3.85)$ & $2(8.3)$ & $7(21.21)$ & $1(33.3)$ & $1(16.66)$ \\
\hline \multirow{4}{*}{$\begin{array}{l}\text { Monobactams, } \\
\text { Carbapenems and } \\
\text { Glycopeptides } \\
\text { groups }\end{array}$} & Aztreonam & - & - & & & $1(4.16)$ & $5(15.15)$ & $1(33.3)$ & \\
\hline & Imipenem & $38(82.61)$ & - & $\begin{array}{l}56 \\
(63.63) \\
\end{array}$ & $61(58.65)$ & $7(29.16)$ & $27(81.82)$ & $2(66.6)$ & $4(66.66)$ \\
\hline & Meropenem & - & - & 32 & $27(25.96)$ & $6(25)$ & $12(36.36)$ & & $2(33.33)$ \\
\hline & Vancomycin & $40(86.9)$ & - & - & $1(0.96)$ & - & - & - & - \\
\hline \multirow{6}{*}{$\begin{array}{l}\text { Broad spectrum } \\
\text { and } \\
\text { Aminoglycoside } \\
\text { groups }\end{array}$} & Chloramphenicol & $39(84.8)$ & $1(14.3)$ & $1(1.13)$ & $32(30.77)$ & $4(16.67)$ & $18(54.54)$ & - & $3(50)$ \\
\hline & Tetracyclin & $38(82.61)$ & $1(14.3)$ & $2(2.27)$ & $48(46.15)$ & $6(25)$ & $12(36.36)$ & - & $3(50)$ \\
\hline & Amikacin & - & $1(14.3)$ & $75(85.2)$ & $45(43.26)$ & $4(16.67)$ & $20(60.6)$ & $1(33.3)$ & $1(16.66)$ \\
\hline & Gentamicin & $20(43.5)$ & $5(71.42)$ & $24(27.3)$ & $30(28.85)$ & $3(12.5)$ & $12(36.36)$ & $1(33.3)$ & $3(50)$ \\
\hline & Streptomycin & $1(2.17)$ & $2(28.5)$ & - & - & - & - & - & - \\
\hline & Tobramycin & $1(2.17)$ & - & $4(4.54)$ & 7 (6.73) & $3(12.5)$ & $7(21.21)$ & $1(33.3)$ & $1(16.66)$ \\
\hline \multirow{6}{*}{$\begin{array}{l}\text { Fluoroquinolones } \\
\text { and Sulfonamide } \\
\text { group }\end{array}$} & Ciprofloxacin & $20(43.5)$ & - & $1(1.13)$ & - & - & $2(6.06)$ & - & - \\
\hline & Gatifloxacin & - & - & $1(1.13)$ & - & - & - & $1(33.3)$ & - \\
\hline & Levofloxacin & $16(34.78)$ & $1(14.3)$ & 32 & $30(28.85)$ & $4(16.67)$ & $12(36.36)$ & $2(66.6)$ & $1(16.66)$ \\
\hline & Norfloxacin & $1(2.17)$ & $1(14.3)$ & $1(1.13)$ & - & $1(4.16)$ & - & - & - \\
\hline & Ofloxacin & $4(8.69)$ & - & $3(36.4)$ & $2(1.92)$ & $2(8.3)$ & $2(6.06)$ & - & $2(33.33)$ \\
\hline & Trimethoprim & $4(8.69)$ & - & - & 7 (6.73) & $1(4.16)$ & $7(21.21)$ & - & $1(16.66)$ \\
\hline \multirow{4}{*}{$\begin{array}{l}\text { Macrolide, } \\
\text { Lincosamide, } \\
\text { Oxazolidinones } \\
\text { and Lipopeptides }\end{array}$} & Clindamycin & $9(19.56)$ & $2(28.5)$ & - & - & - & - & - & - \\
\hline & Erythromycin & $10(21.7)$ & $4(57.1)$ & - & - & $1(4.16)$ & - & & - \\
\hline & Linezolid & $41(89.13)$ & $6(85.7)$ & - & $1(0.96)$ & - & - & - & - \\
\hline & Colistin & $4(8.69)$ & - & $49(55.7)$ & $46(44.23)$ & $12(50)$ & $25(75.75)$ & - & $5(83.3)$ \\
\hline
\end{tabular}


Most of the pathogens showed considerably low susceptibility to cephalosporins including fourth generation cephalosporins. Vancomycin showed highest activity against staphylococcus (86.91\%). Imipenem showed higher activity against staphylococcus $(82.61 \%)$, E. coli $(81.82 \%)$, Enterobacter $(66.66 \%)$, Enterobacteriaceae $(66.66 \%)$.

Amongst broad spectrum antibiotics, amikacin showed $85.2 \%$ susceptibility towards pseudomonas species followed by chloramphenicol and tetracycline showing considerable activity ( $84.8 \%$ and $82.61 \%$ respectively) towards staphylococcus species. Gentamicin showed $71.42 \%$ susceptibility towards streptococcus species.

Among fluroquinolones, ciprofloxacin and levofloxacin showed marked susceptibility towards staphylococcus species $(43.5 \%$ and $34.78 \%$ respectively). Levofloxacin also demonstrated activity towards klebsiella, E. coli and Enterobacter. Linezolid was also found to be effective against staphylococcus and streptococcus species. Those like aztreonam, streptomycin, gatifloxacin and clindamycin showed very less activity towards most pathogens.

\section{DISCUSSION}

Owing to the increased concern which surrounds antibiotic resistance and the changing patterns of bacterial pathogens, the ongoing surveillance of disease and a regular review of the management guidelines are critical. Emergence of multi drug resistance has made management of respiratory tract infections a real challenge. Inappropriate antibiotic use has significantly resulted in drug side effects, allergic reactions and subsequent infections in many instances.

Changing pattern of bacterial pathogens necessitates regular surveillance studies of antibiotic susceptibility at both regional and national levels, which may act as an awareness tool for the prescribing physicians..$^{5-7}$

The present study thus, attempted to probe the antibiotic susceptibility pattern of respiratory pathogens isolated in a tertiary care hospital of eastern India. The present study showed that certain antibiotics, known to be less costly were more effective than high priced antibiotics against certain pathogens. Those with low susceptibility profile thus should not be prescribed as a part of empiric therapy. ${ }^{8,9}$ Thus, a continued periodic updated knowledge of the prevalent antibiogram of the area may also help the professional in better decision making. ${ }^{10,11}$

The therapy should be based on systematic and prompt diagnostic work up and the broad-spectrum antimicrobial treatment which is guided by microbiological support. Unnecessary and irrational antibiotic use may be combated with effective policy implementation with regard to antibiotic usage in critical care and routine set-ups. Over the counter sale of antibiotics should be regulated and restricted to the extent possible. Educational awareness campaigns for both healthcare professionals and general public regarding rational and evidence based antibiotic use are helpful. More ongoing community-based studies are thus needed to identify the best management for individual patients. $^{12}$

\section{CONCLUSION}

Emergence of antimicrobial resistance is a global menace. Inappropriate and irrational drug usage should be avoided. With changing trends in microbiological patterns of responsible organisms, knowledge regarding antibiotic susceptibility pattern needs to be regularly revised, which shall ensure prompt initiation of adequate and appropriate antibiotic treatment with better patient outcomes.

Funding: No funding sources

Conflict of interest: None declared

Ethical approval: The study was approved by the Institutional Ethics Committee

\section{REFERENCES}

1. Shaikh S, Fatima J, Shakil S, Rizvi SM, Kamal MA. Antibiotic resistance and extended spectrum betalactamases: Types, epidemiology and treatment. Saudi J Biol Sci. 2015;22(1):90-101.

2. Coates AR, Halls G, Hu Y. Novel classes of antibiotics or more of the same?. Brit J Pharmacol. 2011;163(1):184-94.

3. Ahmed SM, Abdelrahman SS, Saad DM, Osman IS, Osman MG, Khalil EA. Etiological trends and patterns of antimicrobial resistance in respiratory infections. Open Microbiol J. 2018;12:34.

4. Jenkins SG, Schuetz AN. Current concepts in laboratory testing to guide antimicrobial therapy. In: Mayo Clinic Proceedings. Elsevier. 2012;87(3):290308.

5. Whaley LE, Businger AC, Dempsey PP, Linder JA. Visit complexity, diagnostic uncertainty, and antibiotic prescribing for acute cough in primary care: a retrospective study. BMC Fam Prac. 2013;14(1):120.

6. Johnson AP. Surveillance of antibiotic resistance. Philosophical Trans Royal Soc B Biol Sci. 2015;370(1670):20140080.

7. Mirsoleymani SR, Salimi M, Shareghi Brojeni M, Ranjbar M, Mehtarpoor M. Bacterial pathogens and antimicrobial resistance patterns in pediatric urinary tract infections: a four-year surveillance study (20092012). Inter J Ped. 2014;126142.

8. Zaman SB, Hussain MA, Nye R, Mehta V, Mamun KT, Hossain N. Rev Antibiotic Res Alarm Bells Ring. Cureus. 2017;9(6):1403.

9. Fair RJ, Tor Y. Antibiotics and bacterial resistance in the 21st century. Persp Med Chem. 2014;6:PMCS14459.

10. Lee CR, Cho I, Jeong B, Lee S. Strategies to minimize antibiotic resistance. Inter $\mathrm{J}$ Env Res Pub Heal. 2013;10(9):4274-305. 
11. Franco BE, Martínez MA, Rodríguez MA, Wertheimer AI. The determinants of the antibiotic resistance process. Inf Drug Res. 2009;2:1:11.

12. Paterson DL. The role of antimicrobial management programs in optimizing antibiotic prescribing within hospitals. Clin Inf Dis. 2006;42(2):S90-5.
Cite this article as: Prasad A, Mukherjee S, Era N, Mukherjee M. Antibiotic susceptibility pattern of bacteria isolated from patients of respiratory tract infection in a tertiary care hospital of Eastern India. Int J Basic Clin Pharmacol 2019;8:757-61. 